Bangladesh J. Bot. 40(1): 41-45, 2011 (June)

\title{
MARINE ALGAE OF ST. MARTIN'S ISLAND, BANGLADESH. XII. NEW RECORDS OF RED AND GREEN ALGAE
}

\author{
Abdul Aziz and Mo Towhidur Rahman \\ Department of Botany, University of Dhaka, Dhaka1000, Bangladesh \\ Key words: Ceramium, Caulerpa, Cladophora, Red alga, Green algae, Bangladesh
}

\begin{abstract}
Ceramium tenerrimum (G. Martens) Okamura fa, Caulerpa sertularioides fa corymbosa Taylor and Cladophora vagabunda (L.) Hoek from St. Martin's Island, Bangladesh have been recorded, and described and illustrated for the first time with descriptions and illustrations.
\end{abstract}

\section{Introduction}

So far, 45 taxa of green (Chlorophyceae) and 98 taxa of red (Rhodophyceae) algae have been reported from the St. Martin's Island, Cox’s Bazar, Bangladesh (Ahmed et al. 2008, 2009, Aziz and Rahman 2010, Aziz et al. 2010, Islam et al. 2010). Some of the collections examined, revealed the presence of one red and two green algae which were not recorded earlier in Bangladesh. These are described and illustrated in this account.

\section{Materials and Methods}

Marine algae collected on 6 January 1986 by Professor Syed Hadiuzzaman and on 1 March, 1995 by Professor Abdul Aziz, Department of Botany, University of Dhaka from the St. Martin's Island, Cox's Bazar, Bangladesh were considered. Location and method of preparation of samples are similar to those described in Aziz and Rahman (2010).

\section{Results and Discussion}

Ceramium tenerrimum (G. Martens) Okamura fa, Caulerpa sertularioides fa corymbosa Taylor and Cladophora vagabunda (L.) Hoek are described and discussed below.

\section{Class: Rhodophyceae, Order: Ceramiales, Family: Ceramiaceae Genus: Ceramium Roth}

\section{Ceramium tenerrimum (G. Martens) Okamura fa}

Synonym: Homocetas tenerrimum G. Martens

Habit:Thallus soft, filamentous and unbranched.

Vegetative structure: Plant $2.22 \mathrm{~mm}$ long and $145 \mu \mathrm{m}$ broad at the base, $76.2 \mu \mathrm{m}$ at the median region. Nodes composed of five cell rows where the cells of the middle row larger than the cells of lower or upper rows; nodal cortical cells not of distinct shape, polygonal (tri-, tetra or hexagonal). Branches were not observed and that in the present material cortications absent in the internode, filament apex rounded with appendages from nodal cells and this occur several nodes downward. Internode cells shorter than broad, up to $38.0 \mu \mathrm{m}$ long. Reproductive structures not found.

Note: The present material differs from C. tenerrimum described by Islam (1976, 60, PI, 54, Figs 320-321) by fewer nodal cells and shorter internodal cells and thus illustrated in this paper as a forma of the species. In our material, cortications were also absent in the internodes. So far, $C$. 
fastigiatum Harv., C. gracillimum Griff. et Harv. var. byssoideum (Harv.) G. Mazoyer, C. tenerrimum (G. Martens) Okamura and an unidentified species by Islam (1976); C. cruciatum Collins et Harv., C. fastigiatum fa. flaccidum (Pat) BØrg., C. maryae Weber van Bosse by Islam and Aziz (1987) and C. brevizonatum Peter. (Islam et al. 2002); C. brevizonatum var. caraibica Peter. et Børg. by Islam et al. (2010) have been reported.
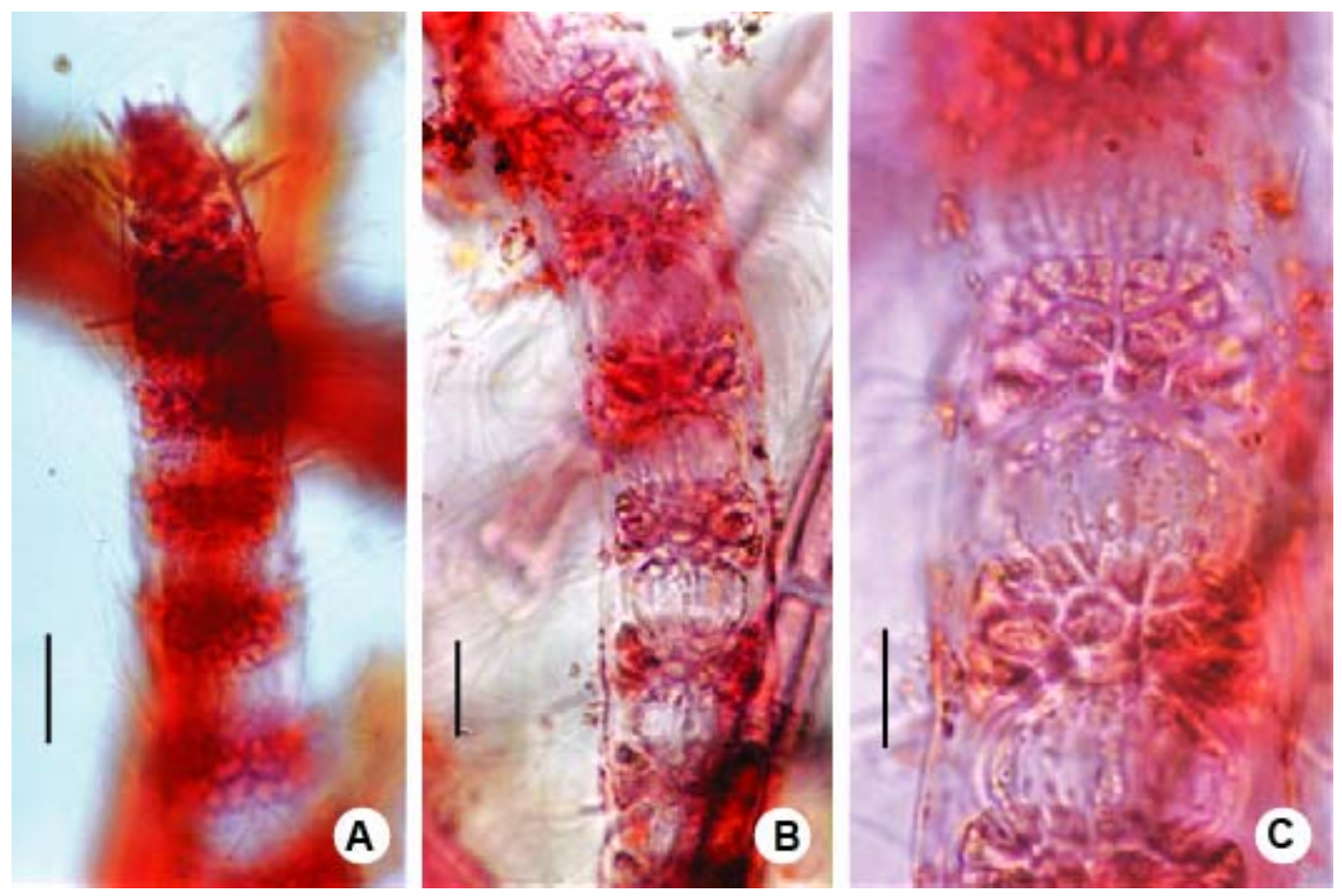

Fig. 1A-C. Ceramium tenerrimum (G. Martens) Okamura fa. A. Terminal part of a thallus. B. Median part of the thallus. C. Two nodes of the thallus enlarged showing rows of nodal cortical cells. Bars: A \& B $=50$ $\mu \mathrm{m}, \mathrm{C}=25 \mu \mathrm{m}$.

Habitat and local distribution: Plants were growing on Liagora harveyana Zeh along with Polysiphonia harveyi Bailey in St. Martin's Island (Islam et al. 2010); collection no. 252; 6 January, 1986; a few.

\section{Class: Chlorophyceae, Order: Siphonales, Family: Caulerpaceae Genus: Caulerpa Lamour.}

\section{Caulerpa sertularioides fa corymbosa Taylor 1960}

(Fig. 2A-C)

(Taylor 1960, 144)

Habit: Plants creeping on rocks with rhizoids below and erect part above.

Vegetative structure: Plants form moderate size colonies, stolons give rise to stout rhizoidbearing branches below and equally strong as short stalked $(0.1-0.2 \mathrm{~cm})$ flat foliar-branches above, the blades, 2.6 - $3.4 \mathrm{~cm}$ long, some of them are branched yielding as many as 6 blades from a single base (giving a corymb-like appearance) attaining a total length of about $7.0 \mathrm{~cm}$; pinnules 
up-curved, regularly and oppositely and very closely placed (about $0.25 \mathrm{~mm}$ gap), about 4 - $6 \mathrm{~mm}$ long up to the near tip where pinnules are shorter giving a nearly rounded appearance of the blade tip; branched blades particularly show rhythmic growth as indicated by to flat constrictions near the median region of fronds.
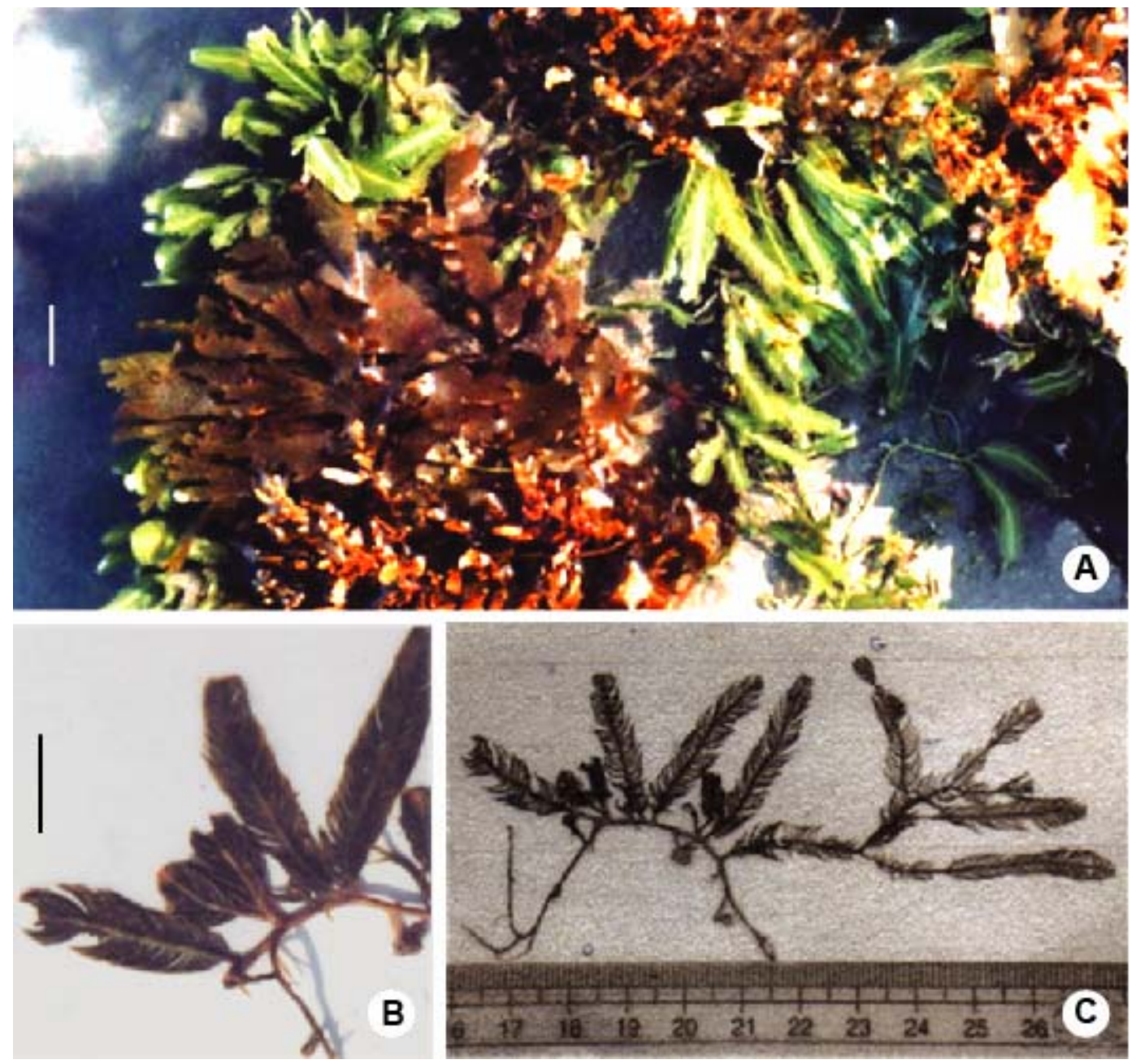

Fig. 2A-C. Caulerpa sertularioides fa corymbosa Taylor. A. Submerged plants with Dictyota at low tide. B. A part of the preserved plant. C. A herbarium specimen of the whole plant showing rhythmic growth of fronds on the extreme right. Bars $=10 \mathrm{~mm}$.

Note: The fronds in fa corymbosa described by Taylor (1960) produces 10 - 20 blades from a single base. Though the number of branches is only 6 , the present material has been placed under fa corymbosa Taylor because the plant is still in a growing state (as many as five young fronds are visible in the Fig. 2C). Caulerpa sertularioides fa typica Børg. described and illustrated by Islam (1976, 22, Fig. 60) resembles to a large extent (rhythmic growth and proliferation of fronds) to $C$. sertularioides fa corymbosa Taylor and the presently described material (Fig. 1C). The fa typica Børg. does not appear as a valid name in the algae database. Thus the material described by Islam 
(1976, Fig. 60) and the present material is considered as C. sertularioides fa corymbosa Taylor. Thus including the present one the total number of taxa stands at 13 (Ahmed et al. 2008).

Habitat and local distribution: Growing on sandy surface of rocks and boulders along with Dictyota in the intertidal zone on the north-west coasts of the St. Martin's Island; collection no. 255; 1 March, 1995; common.

\section{Order: Cladophorales, Family: Cladophoraceae Genus: CladophoraKütz.}

\section{Cladophora vagabunda (L.) Hoek}

(Fig. 3A-C)

Algae Database: www.marinespecies.org, 18 May, 2006

Synonym: C. fascicularis (Mert.) Kütz.

(Børg. 1946, 21, Figs 8, 10)

Habit: Plants densely branched and entangled.

Vegetative structure: Plants more than $1.0 \mathrm{~cm}$ tall, branches opposite, imbricate, very bushy. Cells of the main axis $1.6 \mathrm{~mm}$ wide, basal part narrow, $170 \mu \mathrm{m}$ diameter while the upper end of the cell appear knee like attaining a diameter of $310 \mu \mathrm{m}$. Terminal cell of each branch are much curved than other, may attain a length of $1.4 \mathrm{~mm}$ (outer side) and $1.2 \mathrm{~mm}$ (inner side). Cells of the distal branches remain more or less similar in diameter (less than $150 \mu \mathrm{m}$ ) through most of its length; a single branch or paired branches develop near the tip, nearly imbricately placed; cell tips rounded to slightly conical. Cell wall comparatively thin; chloroplasts reticulate.
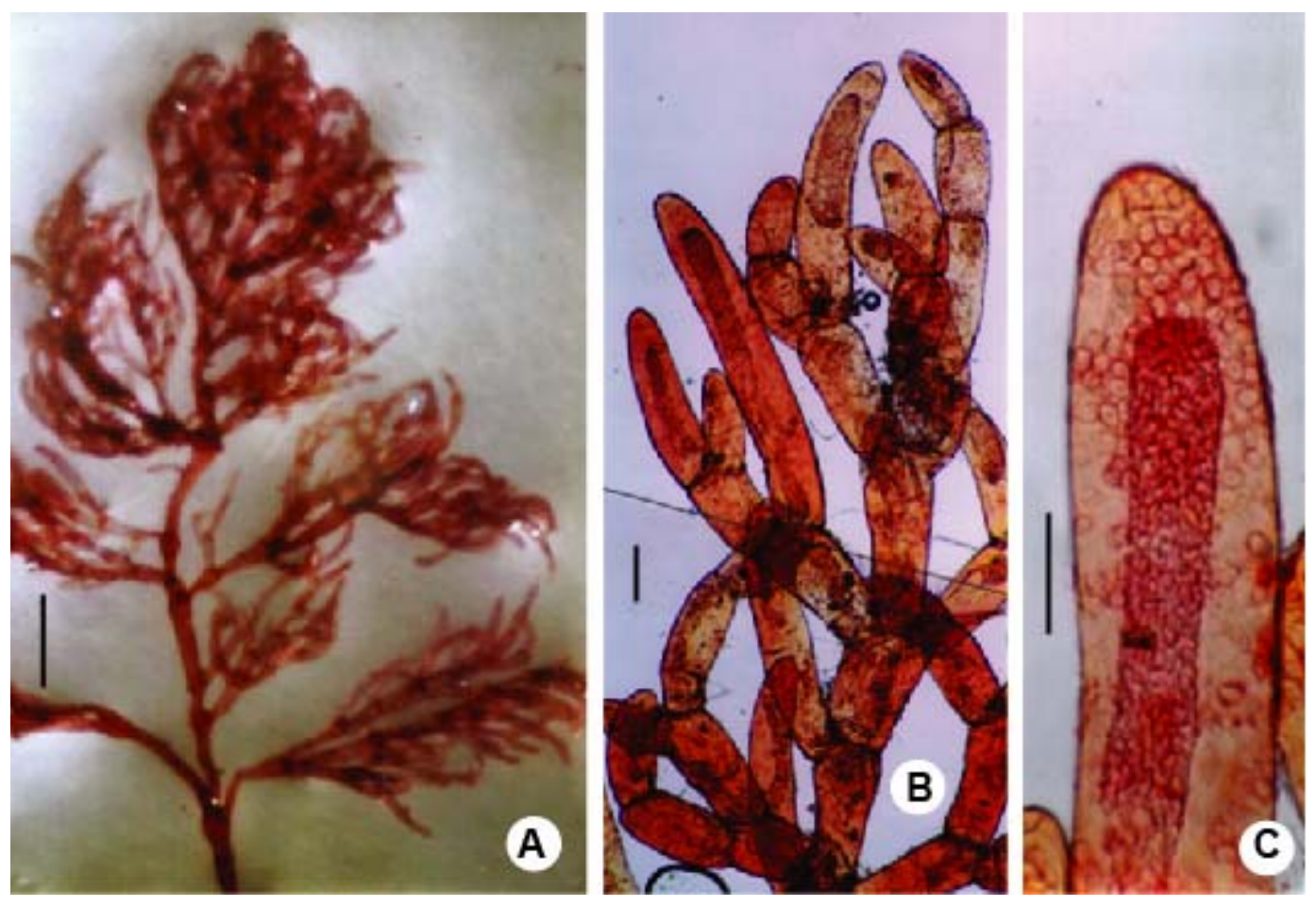

Fig. 3A-C. Cladophora vagabunda (L.) Hoek. A. A major part of a plant showing curled nature of branches. B. A portion of the branch tip. C. Tip of a cell. Bars: A $=100 \mu \mathrm{m}, \mathrm{B}=40 \mu \mathrm{m}, \mathrm{C}=10 \mu \mathrm{m}$. 
Note: The present material appears to agree well with C. vagabunda (L.) Hoek particularly because of the formation of a sort of bundle-like branched structure at the distal part, but gradually narrowed apex of branchlets and presence of imbricate structure lead us to consider it as this species. The whole branching pattern (imbricate) and cell shape and curvature of the distal part appeared at a glance like the distal part of Phylodictyon anastomosans (Harv.) Kraft et Wynne (Aziz et al. 2010) but axis with opposite branches are formed at the very base of the axis, in the present material. Islam (1976) reported C. echinus (Bias.) Kütz. and C. patentiramea (Mont.) Kütz., while Aziz et al. (2010) has recorded C. prolifera (Roth) Kütz. and C. crispula Vickers from the St. Martin's Island.

Habitat and local distribution: The alga was found as a part associated with Liagora harveuiana Zeh (Islam el al. 2010), collected from North West coast of St. Martin's Is., collection no. 255; 1 March, 1995; a few.

\section{References}

Ahmed ZU, ZNT Begum, MA Hassan, M. Khandker, SMH Kabir, M Ahmad, ATA Ahmed, AKA Rahman and EU Haque (Eds) 2008. Encyclopedia of Flora and Fauna of Bangladesh. Vol. 3. Algae, Chlorophyta (Aphanochaetaceae-Zygnemataceae). Asiat. Soc. Bangladesh, Dhaka. 812 pp.

Ahmed ZU, M. Khandker, ZNT Begum, MA Hassan, SMH Kabir, M Ahmad, ATA Ahmed, AKA Rahman and EU Haque (Eds) 2009. Encyclopedia of Flora and Fauna of Bangladesh. Vol. 4. Algae, Chlorophyta (Aphanochaetaceae-Zygnemataceae). Asiat. Soc. Bangladesh, Dhaka. 543 pp.

Algal Database: www.marinespecies.org

Aziz A and MT Rahman 2010. Marine algae of St. Martin's Island, Bangladesh. XI. Red algae (Rhodophyceae). Bangladesh J. Bot. 39(2): 161-168

Aziz A, S Islam and AH Chowdhury 2010. Marine algae of St. Martin’s Island, Bangladesh. X. Green algae (Chlorophyceae). Bangladesh J. Plant Taxon. 17(2): 193-198.

Børgesen F 1946. Some marine algae from Mouritius. Det Kgl. Danske Vidensk. Selskab Biol. Med. 20(6): 1-64.

Islam AKMN 1976. Contribution to the study of the marine algae of Bangladesh. J. Cramer, Bibliotheca Phycologica 19: 1-252.

Islam AKMN and A Aziz 1987. Addition to the list of marine algae of t. Martin’s Island, Bangladesh. III. Red algae. Nova Hedwig. 45: 211-221.

Islam AKMN, A Aziz and A Jahan 2002. Marine algae of St. Martin’s Island, Bangladesh. II. New records of Red algae. Bangladesh J. Bot. 31(1): 23-28.

Islam S, A Aziz and AH Chowdhury 2010. Marine algae of St. Martin's Island, Bangladesh. VIII. New records of Red algae (Rhodophyceae). Bangladesh J. Bot. 39(1): 87-96.

Taylor RW 1960. Marine algae of the eastern tropical and subtropical coasts of the America. Univ. Mich. Press, Ann Arbor. 870 pp. 

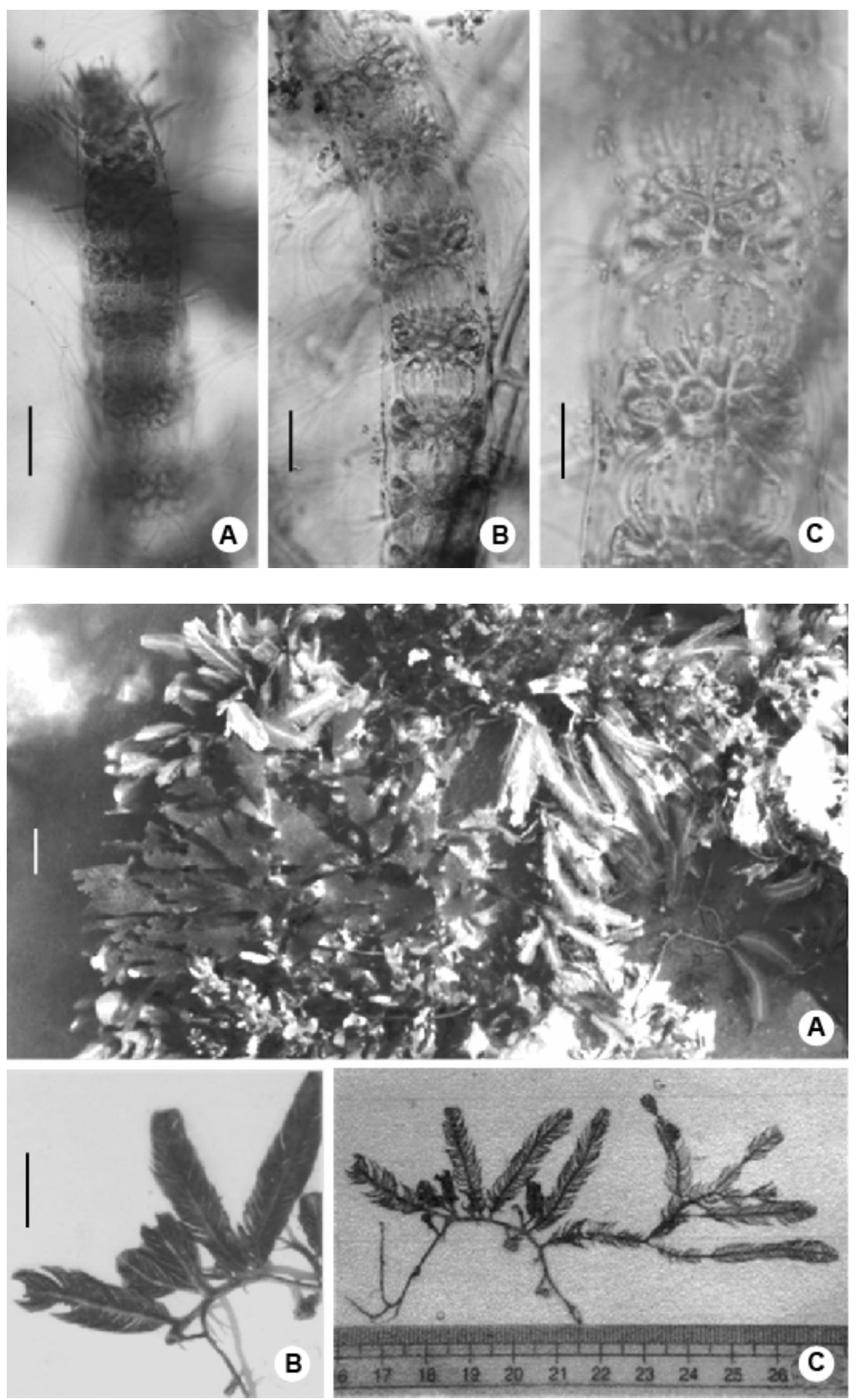

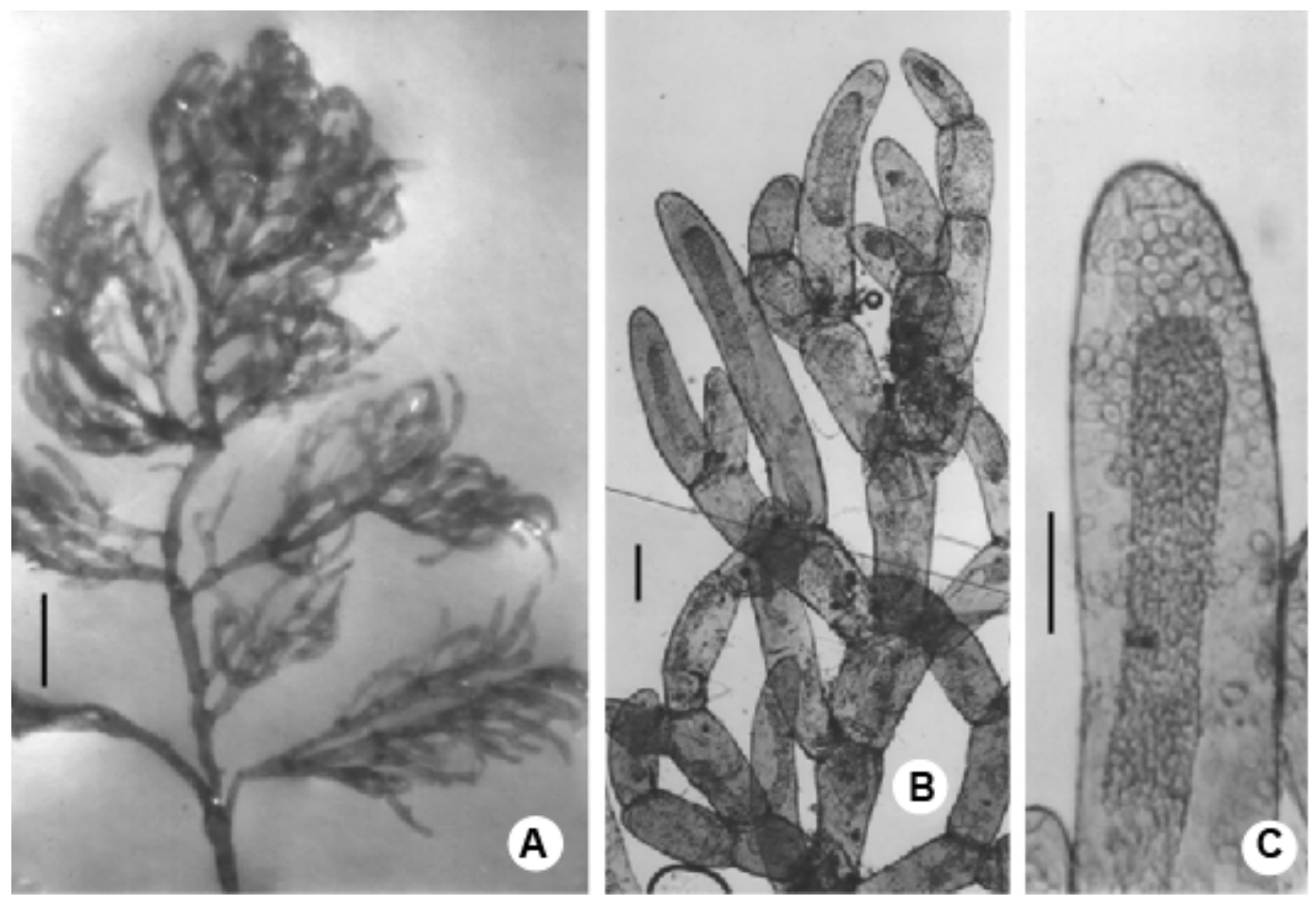